\title{
A Study on the Quality of Drinking Water Disinfection in Small Settlements from Stara Zagora Region, Bulgaria
}

\author{
Gergana SANDEVA ${ }^{1}$, Nikolay SANDEV ${ }^{2 *}$, Rositsa DELIRADEVA ${ }^{1}$, Pavlina GIDIKOVA ${ }^{1}$, \\ Magdalena PLATIKANOVA ${ }^{1}$ \\ ${ }^{1}$ Faculty of Medicine, Trakia University, 6000 Stara Zagora, Bulgaria \\ ${ }^{2}$ Faculty of Veterinary Medicine, Trakia University, 6000 Stara Zagora,Bulgaria \\ * corresponding author: n_sandev@abv.bg \\ Bulletin USAMV series Agriculture 72(1)/2015 \\ Print ISSN 1843-5246; Electronic ISSN 1843-5386 \\ DOI 10.15835/buasvmcn-agr: 11153
}

\begin{abstract}
Introduction: Providing safe drinking water is an integral part of public health and a major task for water supply companies and health control agencies alike. Poor quality disinfection of drinking water significantly increases the risk of water-borne epidemics. In Bulgaria, villages and small towns are affected more often by failures in the disinfection due to negligence from water supply employees and technological limitations. Aims: To determine the qualityofdrinking water disinfectionby measuring significant indicators (free chlorine, E.coli and coliforms) in samples from villages inStaraZagora region.Materials and Methods: Water samples were taken according to protocol directly from water taps in 50villagesin Stara Zagora region. Levels of free chlorine were measured using HACH DR/850 colorimeter and compatible reagents. $100 \mathrm{~mL}$ samples were inoculated with the medium Readycult ${ }^{\circledR}$ Coliforms 100 . The samples were incubated in a thermostat at $37^{\circ} \mathrm{C}$ for 24 hours and E.coli were identified using Kovac's reagent. Results:Only in 5 samples (10\%) free chlorine was adequate to the established norm of $0.3-0.4 \mathrm{mg} / \mathrm{L}$. In 30 villages the levels of free chlorine were below $0.3 \mathrm{mg} / \mathrm{L}$ and cannot guarantee drinking water safety. In 15 villages (30\%) were found coliforms above the acceptable norms (0/100 mL). Nine of these samples were positive for E. coli. Conclusion: The results showed significant deviation from the legally established norms for drinking water safety. More tests will be done to determine whether these problems are incidental or permanent.
\end{abstract}

Keywords: drinking water safety, indicator bacteria, water pollution.

\section{INTRODUCTION}

Providing safe drinking water is an integral part of public health and a major task for water supply companies and health control agencies alike. Poor quality disinfection of drinking water significantly increases the risk of waterborne epidemics, especially among vulnerable demographics like infants, children, and elderly people. The major indicators for drinking water safety monitoring are the level of free chlorine and some microorganisms (coli forms and Escherichia coli). Their safe limits are stated in European and national law as well as in the WHO Guidelines of
Drinking-water Quality. According to Bulgarian regulation the optimal levels of free chlorine at the consumer are $0.3-0.4 \mathrm{mg} / \mathrm{L}$. The norms for coli form and E. coli contamination are $0 / 100 \mathrm{~mL}$, i.e. a $100 \mathrm{~mL}$ water sample should be free of those bacteria.

The aim of this study was to determine the quality of drinking water disinfection by measuring significant indicators (free chlorine, E. coli and coli forms) in samples from villages aroundStara Zagora and evaluate the potential risk of bacterial intestinal infections for the target population. 


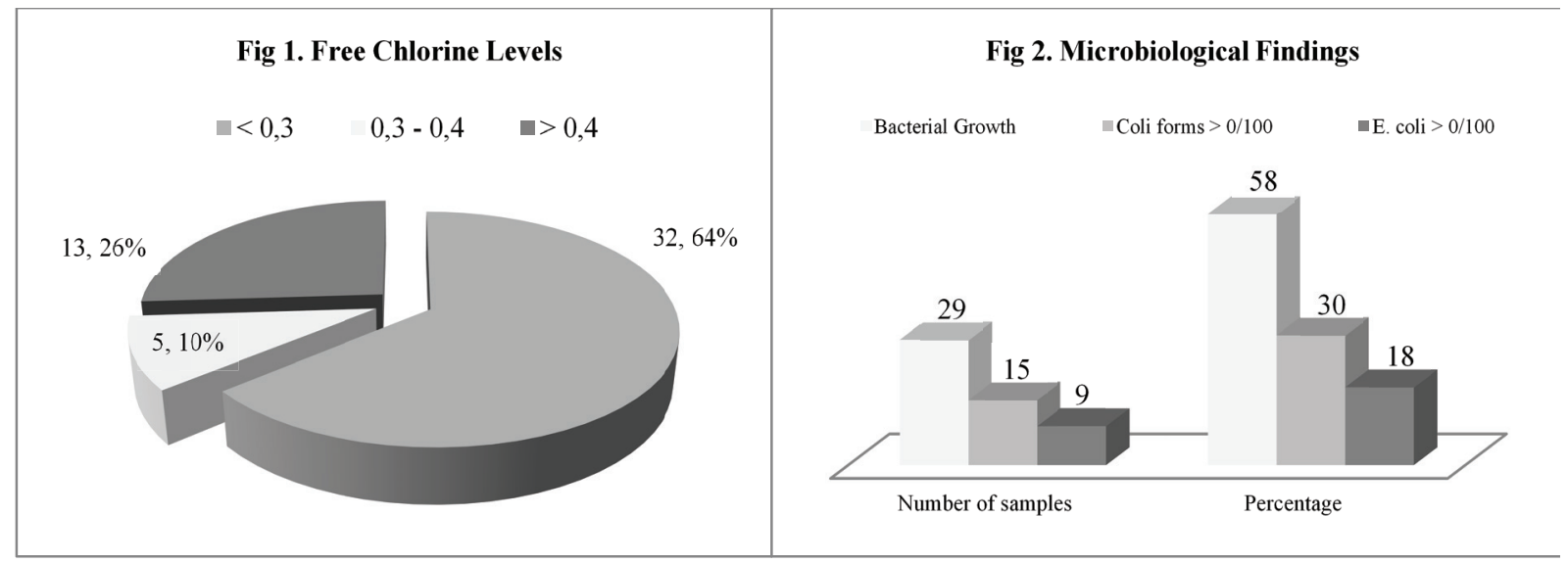

Tab. 1. Free chlorine levels and microbiological findings in drinking water samples from villages in Stara Zagora region (monitoring data for years 2011-2013).

\begin{tabular}{|c|c|c|c|c|c|c|c|c|c|c|c|c|c|c|}
\hline \multirow[t]{2}{*}{ Year } & \multicolumn{2}{|c|}{$\begin{array}{c}\text { Free } \mathrm{Cl} \quad 0 \\
\mathrm{mg} / \mathrm{L}\end{array}$} & \multicolumn{2}{|c|}{$\begin{array}{c}\text { Free } \mathrm{Cl} 0,1 \\
\mathrm{mg} / \mathrm{L}\end{array}$} & \multicolumn{2}{|c|}{$\begin{array}{c}\text { Free } \mathrm{Cl} 0,2 \\
\mathrm{mg} / \mathrm{L}\end{array}$} & \multicolumn{2}{|c|}{$\begin{array}{c}\text { Free } \mathrm{Cl} 0,3 \\
\mathrm{mg} / \mathrm{L}\end{array}$} & \multicolumn{2}{|c|}{$\begin{array}{c}\text { Free } \mathrm{Cl} 0,4 \\
\mathrm{mg} / \mathrm{L}\end{array}$} & \multicolumn{2}{|c|}{$\begin{array}{c}\text { Coli forms }> \\
0 / 100\end{array}$} & \multicolumn{2}{|c|}{$\begin{array}{c}\text { E. coli > } \\
0 / 100\end{array}$} \\
\hline & $\mathrm{N}$ & $\%$ & $\mathrm{~N}$ & $\%$ & $\mathrm{~N}$ & $\%$ & $\mathrm{~N}$ & $\%$ & $\mathrm{~N}$ & $\%$ & $\mathrm{~N}$ & $\%$ & $\mathrm{~N}$ & $\%$ \\
\hline 11 & 60 & 27,3 & 51 & 23 & & 21 & & 13 & & & & 0,5 & & 0,5 \\
\hline 01 & 64 & 26,1 & 60 & 24, & 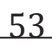 & 21, & 48 & 19, & & 8,2 & & 1,6 & & 0,4 \\
\hline 2013 & 58 & 26,1 & 65 & 29,3 & 46 & 20,7 & 25 & 11,3 & 28 & 12,6 & 1 & 3,6 & 2 & 0,9 \\
\hline
\end{tabular}

\section{MATERIALS AND METHODS}

Water samples were taken a few days after a period of intense rainfall at the end of March 2014 according to protocol directly from water taps in 50 villages (population 21,468) aroundStara Zagora. Levels of free chlorine were measured immediately after taking each sample using HACH DR/850 colorimeter. $100 \mathrm{~mL}$ samples were inoculated with the medium Readycult ${ }^{\circledR}$ Coliforms 100 by MERCK. The samples were incubated in a thermostat at $37^{\circ} \mathrm{C}$ for 24 hours and E. coli were identified using Kovac's reagent.

Additionally, we analyzed monitoring data for the studied 50 villages collected by the Regional Health Inspection - Stara Zagora in the years 2011, 2012, and 2013.

\section{RESULTS AND DISCUSSION}

Only in 5 samples (10\%) the free chlorine was in the norm of $0.3-0.4 \mathrm{mg} / \mathrm{L}$. In 32 villages $(64 \%)$ the levels of free chlorine were below $0.3 \mathrm{mg} / \mathrm{L}$ - levels which cannot guarantee drinking water safety (Fig 1). The microbiological findings are shown on Figure 2. In 15 villages (30\%) were found coli forms above the acceptable norms of $0 / 100$ $\mathrm{mL}$ (Fig 2). Nine of these samples were positive for
E. coli; Yersinia was isolated from one of the coli form-positive samples. It was quite evident that free chlorine levels below $0.3 \mathrm{mg} / \mathrm{L}$ resulted in increased frequency of coli form positive samples and in greater risk for the population.

The analyzed data from the Regional Health Inspection - Stara Zagora for the period 20112013 showed similar results as regards to the free chlorine levels but quite different microbiological findings (Table 1). Of all the samples taken, in $73.4 \%$ free chlorine levels were below the sanitary minimum of $0.3 \mathrm{mg} / \mathrm{L}$. But, surprisingly, only 12 coli form positive $(1.75 \%)$ and 4 E. coli positive $(0.6 \%)$ samples were registered for the whole period.

\section{CONCLUSION}

The results of the study showed significant deviation from the legally established norms for drinking water safety and are a cause of serious concern for the health of the population in small settlements around the town of Stara Zagora. More tests will be done by our research team to determine whether these problems are incidental or permanent. 